\title{
Design and technological capabilities of a universal forging mill
}

\section{Konstrukcja i możliwości technologiczne uniwersalnej walcarki kuźniczej}

JANUSZ TOMCZAK ARKADIUSZ TOFIL *
DOI: https://doi.org/10.17814/mechanik.2017.11.158
The paper presents selected results of the research related to the development and verification of a multi-purpose construction of forging mill suitable for the following processes: longitudinal roll forging, cross-wedge rolling, and steel bar cropping. Modern CAD/CAE numerical tools have been used to facilitate the design and analysis of the construction. The designed forging mill is characterized by high versatility due to the possibility of two different kinematic processes of roll forging (longitudinal and transverse) as well as semi-products waste-free cropping. Its technological capabilities are considerably higher as compared to the machines currently used in industry. Verification of adopted construction solutions was made during the commissioning tests. The achieved results have fully confirmed the usefulness of multi-task forging mill for rolling forgings and preforms as well as cropping process. KEYWORDS: roll forging mills, longitudinal rolling, cross wedge rolling, bar cropping processes

Domestic forging industry is characterized by a great variety of assortment of manufactured products and relatively small series of forgings. Such specificity of production urges the use of a fairly broad group of forging machines. This also applies to the processes of forge rolling, where forges use various types of rolling mills to shape forgings and blanks. Currently offered roll forging mills are designed for the implementation of one of the rolling scheme: longitudinal or transverse [1-5]. What is lacking is the universal machine, which would allow for the implementation of both processes. In addition, commercially available forged steel mills (mainly from foreign producers) are relatively expensive, and their operation becomes cost-effective only in the case of bulk and mass production. Therefore, it was considered purposeful to develop of own roll forging mills design tailored to the needs of domestic market. One of the innovative machines that came into being as a result of this work, is a universal forging mill designed for: transverse rolling, longitudinal rolling and waste-free split $[6,7]$. The machine was installed at the State Higher Vocational School in Chełm. Currently, there are

\footnotetext{
* Dr hab. inż. Janusz Tomczak (j.tomczak@pollub.pl), dr hab. inż. Arkadiusz Tofil (atofil@pwsz.chelm.pl) - Wydział Mechaniczny Politechniki Lubelskiei
}

practically no rolling mills with such a broad technological possibilities worldwide.

\section{Construction of a universal roll forging mill}

The multipurpose forging mill is very versatile - it allows two different kinematic processes for forging and non-waste division of blanks. The main assumption determining its design was the possibility of changing the direction of rolls rotation - this solution ensures the realization of the rolling processes (rolls rotate in the same direction) and longitudinal rolling (rolls rotate in opposite directions) in one aggregate. Tool dimensions were determined on the basis of the extended range of forgings shaped by national forges [8, 9]. It was assumed that the effective diameter of the rollers should allow embedding these wedge tools length in the expansion of up to $1400 \mathrm{~mm}$ (in the case of cross-wedge rolling) and shaping the forging of a length of $900 \mathrm{~mm}$ (in the case of longitudinal rolling). In addition, the mill should be designed for no-waste splitting of steel rods up to $60 \mathrm{~mm}$ in diameter. For operational reasons, the rolls after a full rotation must be able to stop immediately.

The designed roll forging mill has a segmental structure and consists of seven basic units (fig. 1).

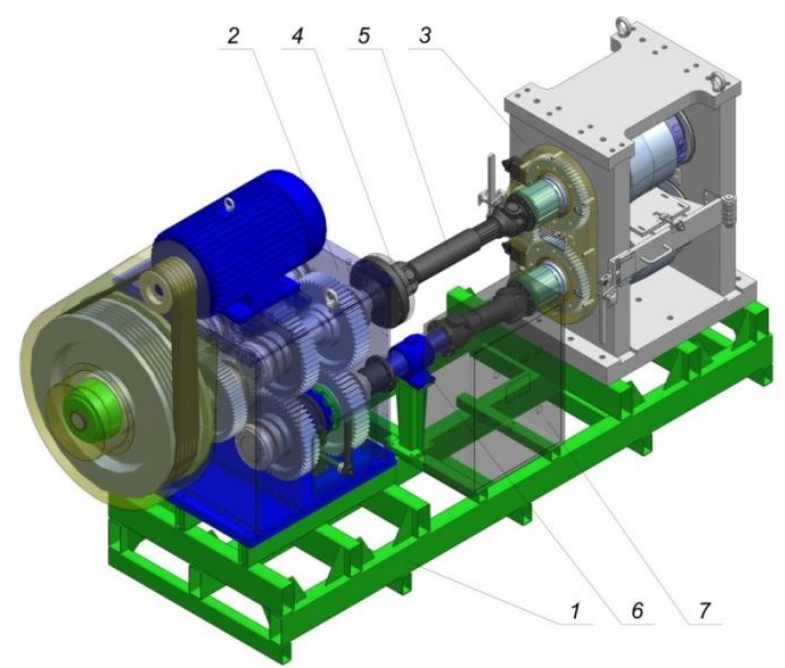

Fig. 1. Spatial model of universal roll forging mill: 1 - carrier frame, 2 - drive unit, 3 - working cage, 4 - clutch, 5 - pivot shaft, 6 - torque converter, 7 - electrical box 


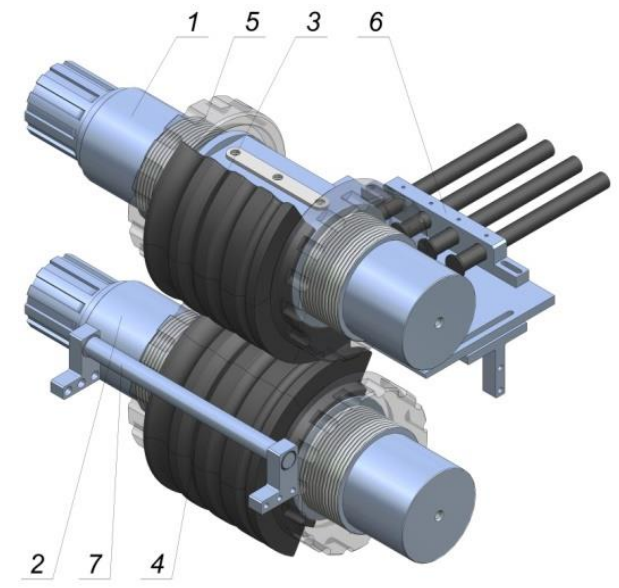

Fig. 2. Method of armoring the working space of rolling mill for longitudinal rolling: 1,2-working shafts; 3,4 - sets of working segments; 5 - front nut; 6 - bumper assembly; 7 -support

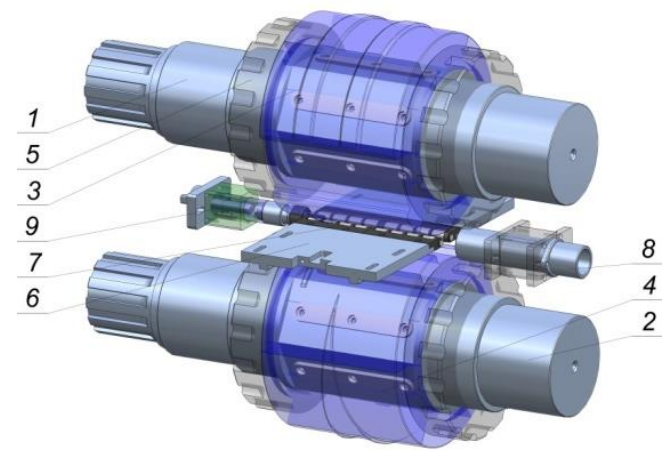

Fig. 3. Method of armoring the rolling mill for transverse rolling: 1, 2 - shafts; 3, 4-working segments; 5 - front nut; 6 - guides; 7 - guide rails; 8 - batch feeder; 9 - bumper

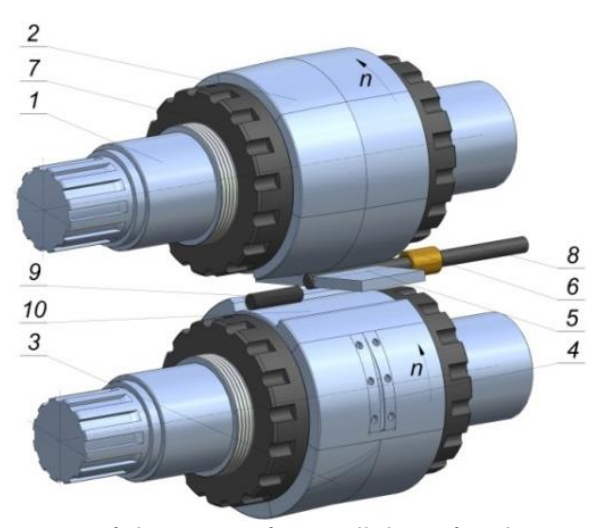

Fig. 4. Diagram of the waste-free splitting of rods: 1 - shaft, $2-$ upper tools, 3 - lower tools, 4 - knife, 5 - guide, 6 - insertion sleeve, 7 - head nut, 8 - bar for splitting, 9 - semi-product cut, 10 - semi-prefabricated outlet

A support frame is made as openwork welded structure. The drive unit is attached to the frame and the cage of the working rolls on the other side. The pivot shafts available for sale are used for transferring the torque from the power unit to the working roll cage. A coupling is provided in the drive transfer system to the upper roll of the working frame to allow the tool to set the tool in angular position. In contrast, in the drive transition system to the lower roller, a measuring group consisting of a torque transducer, and angular displacement transducer, was placed. The measuring system is used for recording kinematic parameters of the force, and the rolling process. The machine is equipped with integrated power supply and control. It allows electric power to drive the electric motor and additional control equipment. The basic component of forging mill is the cage of work rolls, which is implemented in the process of deformation of the material. The roll cage body was made as a folding structure made of vertical steel plates, which serve as a stand. They are bent by means of two horizontal plates, which stiffen the structure. Work shafts are mounted on the work cage racks with tool segments placed on them. During operation, depending on the configuration of the mill, the shaft can rotate in the same direction at the same speed or in opposite directions. Depending on the rolling method, the cage work space will be used to construct tools adapted to the process. To the longitudinal rolling of the forging tool, segments are used mounted only on the portion of the circumference of rollers (up to $270^{\circ}$ around the circumference of rolls [1012]). On the working surfaces of segments, there are groove-shaped patterns, in which crushing the material occurs during counter-rotation of the rolls. Schematic armoring of the rolling mill for longitudinal forging is shown in fig. 2.

During longitudinal rolling, the rollers rotate in opposite directions, and the working segments placed on them engage the material, causing it to crunch and move along the axis of the rolled forgone. In the case of lateral rolling or waste-free splitting, the tool segments are usually located around the periphery of the roller. The layout of the transverse rolling tools is shown in fig. 3 . In this case, the tools have the shape of cylinders placed on the workpiece surfaces. In addition, the rolled material is maintained in the working space by two guides. The blank is fed to the working space along the axis of rolling. The axial alignment of the load is accomplished by means of an axial stop.

On the universal forging mill, it is also possible to make a waste-free splitting of the bars. The idea of nowaste splitting consists in adopting the cross-wedge rolling process with rotary tools to form a notched ring at the splitting site and then cyclically bending the broken bar during its rotary motion between the conical tool surfaces (fig. 4).

The rods for splitting are fed into the working space through the inserting sleeve located in a working cage rack. The length of the split log is determined by means of a bumper located in the second stand. Cut bars are automatically removed from the operating space, so that the process can be continuously carried out without stopping the rolling mill.

On the basis of developed machine design, a prototype forged mill has been manufactured. View of the machine is shown in fig. 5 and its important technical data are summarized in the table.

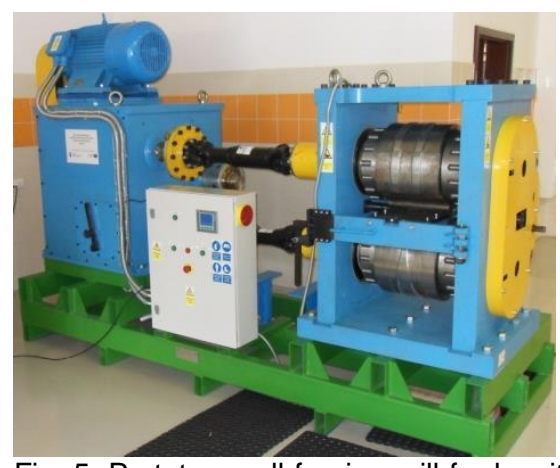

Fig. 5. Prototype roll forging mill for longitudinal and transverse rolling as well as waste-free splitting 
TABLE. Parameters of universal roll forging mill

\begin{tabular}{|l|r|}
\hline Drive motor power, $\mathrm{kW}$ & 37 \\
\hline Speed of electric motor, rpm & 960 \\
\hline Rotational speed of working shafts, rpm & 16,5 \\
\hline Nominal torque on the drive shaft, $\mathrm{Nm}$ & 12500 \\
\hline Maximum torque on the drive shaft, $\mathrm{Nm}$ & 20000 \\
\hline Nominal diameter of rolls, $\mathrm{mm}$ & 300 \\
\hline Length of barrel rolls, $\mathrm{mm}$ & 430 \\
\hline Minimum axle distance, $\mathrm{mm}$ & 470 \\
\hline Maximum axle distance, $\mathrm{mm}$ & 9500 \\
\hline Machine weight, $\mathrm{kg}$ & 2120 \\
\hline Machine height, $\mathrm{mm}$ & 1430 \\
\hline Machine width, mm & 3490 \\
\hline Machine length, $\mathrm{mm}$ & \\
\hline
\end{tabular}

\section{Movement tests}

In order to confirm the technological possibilities of the universal forging mill, tests for transverse and longitudinal rolling of forgings and for the waste-free splitting of bars were carried out. It has been assumed that in the rolling process, the steel rolls of the rollers will be formed in the shape of a rod section (fig. 6).

The longitudinal and transverse rolls were made of $\mathrm{C} 45$ steel rods that were heated to $1150^{\circ} \mathrm{C}$. During the longitudinal rolling tests, the charge was kept constant in the clamps. After inserting the heated material into the oval cutout and positioning it with the buffers, the rollers were rotated in opposite rotation. After the complete rotation of the tools, the rollers stopped and the forging was rotated $90^{\circ}$ to the next circular cut. Then, the counter rotational movement of the rollers was started again and the forging stages of circular cross-section were formed (fig. 7).

For cross-wedge forgings rolling, the rollers are fitted with wedge work tools (fig. 8a). A warmed up charge was then introduced into the tool input zone and the rollers were then rotated in the same direction. During rolling, the blank was held in the working space by 2 guides. After full rotation of the tools, the rollers were automatically stopped and the formed shape was removed from the working space (fig. $8 b$ ).

The study also included attempts to split steel bars with a diameter of $\varnothing 30 \mathrm{~mm}$ into sections of length $I=100$ $\mathrm{mm}$. For this purpose, the mill was equipped with a set of tools that allow simultaneous pressing of the notch, followed by a rotary bending of the material until it ruptures in the area of the notch (fig. 9a). During the process, the split rod is fed between rollers that rotate at constant speed in the same direction. The length of the split segments is determined by the bumper. The splitting process takes place at full rolls. The obtained semifinished products are characterized by a satisfactory separation surface (fig. $9 b$ ), they are free of defects that occur during breaking of bars by means of other methods.

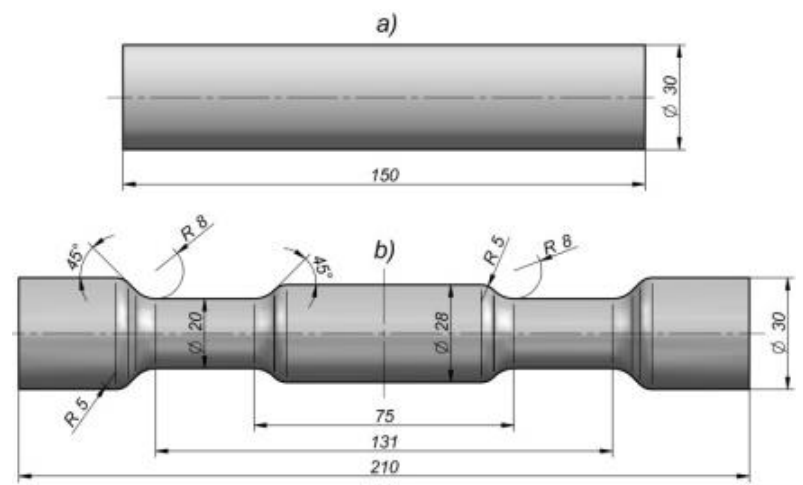

Fig. 6. Shape and dimensions of forgings of graduated roller for rolling in a forging mill: a) blank, $b$ ) forging
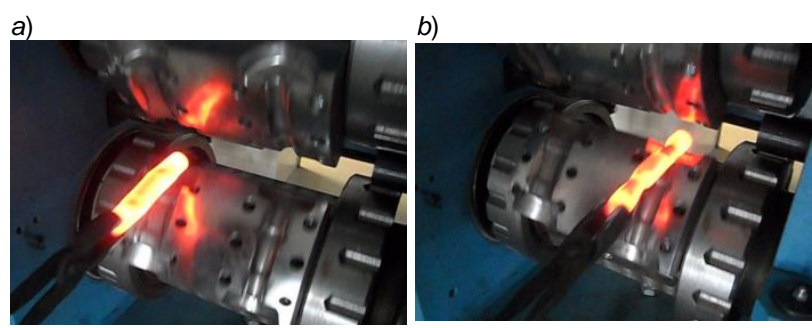

Fig. 7. Samples of rolling the forging of a graduated roller: a) forging after the $1^{\text {st }}$ passage, $b$ ) forging after the $2^{\text {nd }}$ passage
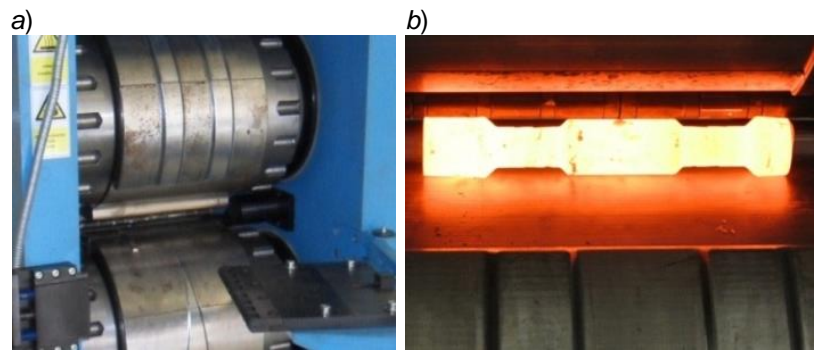

Fig. 8. Samples of cross-wedging rolling of graduated forging: a) wedge tools, $b$ ) shaped forging
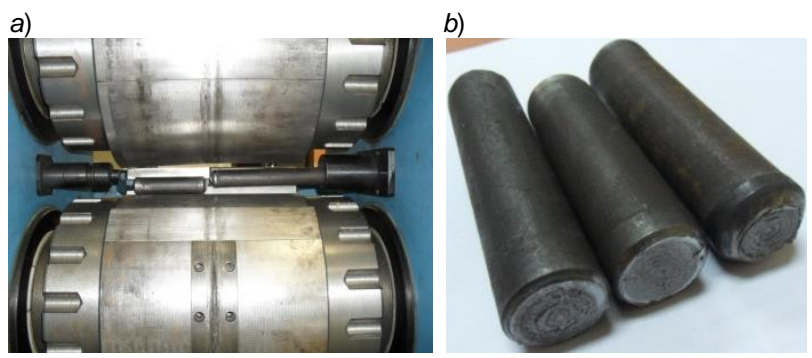

Fig. 9. Implementation of the waste-free splitting process: a) final stage of a process with a separated blank, b) obtained sections of the bars

\section{Conclusions}

The proposed constructional solution of the multipurpose forging mill may interest domestic and foreign plants from the forging industry. The innovativeness of the presented rolling mill results from the possibility of realizing longitudinal and transverse rolling and the waste-free splitting of rods. At present, there are no such machines on the market, and the specialized rolls offered 
(transverse and longitudinal mills) are relatively expensive and are designed to form a narrow product group. In the case of short production runs and a wide range of products, the purchase of two specialized machines becomes unprofitable. As a result, forges are forced to use alternative technologies that are characterized by greater material and energy consumption, which is why they are so competitive. It is important to note that the rolling process - due to numerous advantages - is increasingly used. There is also great potential for waste-free splitting, which can be successfully implemented in universal mills.

Experimental verification of the developed multi-task roll mill design has fully confirmed the technological capabilities of the machine. Obtained forgings were in accordance with accepted assumptions (geometrical and dimensional). Performed motion tests also showed that the developed design fulfills accepted assumptions regarding rigidity and bearing capacity.

\section{REFERENCES}

1. "ASM Metal Handbook". 14 (1996). "Forming and Forging".

2. Bartnicki J., Pater Z. "The aspects of stability in cross-wedge rolling processes of hollowed shafts". Journal of Materials Processing Technology. 155-156 (2004): pp. 1867-1873.

3. "Cross-Wedge and Forging Rolls". www.lasco.de (access: 03.05.2016 r.).

4. Pater Z. "Cross-Wedge Rolling". Comprehensive Materials Processing. 3 (2014): pp. 211-279.

5. Pater Z. "Walcowanie poprzeczno-klinowe". Lublin: Wydawnictwo Politechniki Lubelskiej, 2009.

6. Tofil A., Pater Z., Tomczak J. „Dwuwalcowa klatka walcownicza, zwłaszcza do walcowania poprzecznego, wzdłużnego oraz dzielenia bezodpadowego". Patent No. PL 215512, 2013.

7. Tofil A., Tomczak J., Pater Z. „Przekładnia redukcyjna ze zmiennym kierunkiem obrotów wałów wyjściowych, z możliwością pomiaru momentu obrotowego". Patent No. PL 219484, 2013.

8. Tofil A. „Procesy kształtowania półwyrobów w uniwersalnej walcarce kuźniczej". Lublin: Wydawnictwo Politechniki Lubelskiej, 2016.

9. Bulzak T., Tomczak J., Pater Z. „Prognozowanie wpływu konstrukcji walcarki ramowo-konsolowej na możliwości jej użytkowania". Mechanik. 87, 2 (2014): pp. 100-104.

10. Lisowski J. "Walcowanie kuźnicze”. Warszawa: Wydawnictwa Naukowo-Techniczne, 1974

11. Grass H., Krempaszky C., Werner E. "3-D FEM-simulation of hot forming processes for the production of a connecting rod". Computational Materials Science. 36 (2006): pp. 480-489. 12. Li R., Jiao S. "Numerical simulation for precision roll-forging of automobile front axle". Advanced Materials Research. 602604 (2013): pp. 1850-1854. 